\title{
Article processing charge (APC)
}

Bo-Christer Björk, David Solomon

\section{Source}

https://wellcome.ac.uk/sites/default/files/developing-effective-market-for-open-accessarticle-processing-charges-mar14.pdf Bo-Christer Björk and David Solomon. (2014). Developing an Effective Market for Open Access Article Processing Charges (Report). Wellcome Trust.

A fee often charged by full OA journals as well as by hybrid journals for the OA dissemination services provided. These charges are the major source of revenue for professional OA publishers. 